\title{
PENGEMBANGAN STRATEGI MULTIPLE INTELLIGENCES PADA PEMBELAJARAN BERNEGOSIASI SISWA KELAS XI SMK MUHAMMADIYAH 1 PASURUAN
}

\author{
Ilmiyatur Rosidah \\ Mahasiswa Magister Pendidikan Bahasa Indonesia
}

\begin{abstract}
Abstrak: Tujuan penelitian ini adalah mengembangkan strategi pembelajaran, pada pembelajaran bernegosiasi siswa kelas XI SMK Muhammadiyah 1 Pasuruan, yang diharapkan dapat meningkatkan kemampuan siswa dalam bernegosiasi. Pengembangan strategi ini menggunakan pengembangan yang diadaptasi dari model pengembangan Dick \&Carey (1990). Strategi ini dikembangkan dari analisis kebutuhan peserta, guru, dan karakteristik peserta didik dengan teknik angket, observasi, tes, dan dokumentasi. Setelah melakukan analisis kebutuhan langkah selanjutnya adalah merumuskan tujuan, analisis pembelajaran, kemudian mengembangkan rancangan strategi pembelajaran. Langkah selanjutnya adalah melakukan uji validitas ahli dan melkukan revisi, kemudian uji coba pada kelas. Strategi yang dikembangkan pada penelitian ini adalah strategi multiple intelligences. Hasil penggumpulan data menunjukkan sebagai berikut. Analisis kebutuhan siswa menunjukkan: dibutuhkan strategi pembelajaran baru yang lebih memotivasi dan mengaktifkan peserta didik, materi negosiasi perlu mendapat penjelasan lebih rinci agar peserta didik mendapat pemahaman konsep lebih baik dan benar, sehingga peserta didik mampu bernegosiasi dengan baik. Peserta didik secara umum mengalami kesulitan belajar bernegosiasi, apalagi dengan peserta didik dengan gaya belajar audiovisual. Karena peserta didik dengan tipe ini sangat sulit untuk berinteraksi/ berbicara depan umum, kekurangan peserta didik dalam belajar bernegosiasi adalah trik atau cara mudah untuk benegosiasi. Produk yang dihasilkan pada penelitian ini berupa model pembelajaran dengan strategi multiple intelligences yang dikembangkan pada rencana pelaksanaan pembelajaran dan handout.
\end{abstract}

Kata Kunci : pengembangan, strategi multiple intelligences, negosiasi.

Penelitian ini merupakan suatu usaha meningkatkan mutu pembelajaran bernegosiasi siswa kelas XI SMK Muhammadiyah 1 Pasuruan. Dalam mewujudkan bangsa Indonesia sebagai bangsa yang sejahtera, maka masyarakat Indonesia harus menjadi masyarakat yang berkualitas dan memiliki pemikiran- pemikiran yang cerdas. Hal tersebut, ditempuh dengan memperoleh pendidikan yang baik.
Seperti yang tertera pada undang-undang sistem pendidikan Nasional (No. 2 tahun 2003 kuhusunya pasal 3), Pendidikan berfungsi mengembangkan kemampuan dan membentuk watak serta peradaban bangsa yang bermartabat dalam rangka mencerdaskan kehidupan bangsa, bertujuan untuk mengembangkan potensi peseta didik, agar menjadi manusia yang beriman dan bertawa kepada tuhan Yang Maha Esa, berakhlak 
mulia, sehat, berilmu, cakap, kreatif, mandiri, dan menjadi warga Negara yang demokratis serta bertanggung jawab.

Untuk mewujudkan tujuan tersebut, pemerintah telah menjabarkan tujuantujuan itu dalam tujuan pembelajaran yang termuat dalam kurikulum. Salah satunya adalah kompetensi dasar 2.10 yaitu, bernegosiasi yang menghasilkan dalam konteks bekerja pada jenjang sekolah menengah kejuruan (SMK).

Kemampuan negosiasi ini merupakan salah satu keterampilan yang harus dikuasai siswa dalam proses pembelajaran, dimana Pemerintah dalam kurikulum membekali peserta didik kemampuan negosiasi yang bertujuan untuk menghasilkan input yang siap bersaing dikehidupan sosial khususnya dalam dunia usaha/ kerja. Seperti halnya yang dikemukakan oleh (Browdo, 2008: 11) bahwa, orang mempunyai seni bernegosiasi biasa mempunyai kehidupan yang lebih mudah. Karena pada hakikatnya manusia adalah makhuk sosial, suatu tindakan tempat saling bertukar pengalaman, saling mengemukakan dan menerima pikiran, saling mengutarakan perasaan atau saling mengesprasikan, serta menyetujui suatu pendirian atau menyakinkan (Tarigan, 2008:8). Pendapat tarigan tersebut tercermin dalam kegiatan negosiasi, maka kompetensi tersebut sangat penting diberikan oleh siswa SMK. Dalam pembelajaran negosiasi siswa tidak hanya dibekali pengetahuan tentang konsep bernegosiasi saja, akan tetapi implementasi kegiatan negosiasi itu sendiri. Dewasa ini, yang lihat pada pola pembelajaran masih bersifat menonjolkan konsep-konsep secara langsung. Pembelajaran tersebut dapat digambarkan dengan, pengajaran tentang teori/ definisi, kemudian contoh, dan selanjutnya latihan-latihan soal. Semua dilakukan tanpa mempertimbangkan efektivitas dan target dari hasil pembelajaran, karena guru hanya mengejar target waktu. Pola pembelajaran yang demikian membuat lingkungan belajar menjadi kondusif, yang membuat anak cenderung bosan dan mengalami penurunan motivasi belajar, karena mengalami motivasi belajar, maka siswa kurang memperhatikan pelajaran, dan mengakibatkan siswa tidak memahami pelajaran dan akibat yang paling parah adalah siswa tidak menyukai pelajaran tersebut.

Selain merumuskan tujuan yang ingin dicapai melalui SK/KD, Pemerintah secara berkesinambungan melakukan berbagai cara meningkatkan kualitas pendidikan. Dan salah satunya adalah, meningkatkan kualitas pembelajaran di kelas. Mulai dari mengembangakan strategi pembelajaran maupun media yang dipakai untuk menunjang proses pembelajaran.

Pembelajaran dengan mengopti-malkan potensi yang dimiliki oleh siswa/peserta didik, diharapkan siswa mampu mencapai tujuan pembelajaran sesuai dengan potensi yang mereka miliki. Hal tersebut akan menjadikan sebuah proses pembelajaran lebih bermakna, efisien, serta selalu memstimulus motivasi siswa dalam belajar.

Penelitian ini merupakan usaha untuk meningkatkan mutu/ kualitas pembelajaran negosiasi peserta didik kelas XI SMK Muhammadiyah 1 Pasuruan. Kemampuan negosiasi peserta didik SMK 1 Muhammadiyah Pasuruan dirasa belum memenuhi tujuan yang kompetensi. Hal tersebut dapat dilihat dari hasil atau prestasi didik pada kompetensi yang dicapai. Memang banyak faktor yang menyebabkan kenapa pembelajaran negosiasi di SMK Muhammadiyah 1 Pasuruan belum mencapai tujuan kompetensi.

Pada pelaksanaan pembelajaran ne-gosisasi, seringkali peserta didik kurang mampu melakukan negosiasi 
dengan baik. peserta didik cenderung malu dan tidak percaya percaya diri ketika melakukan kegiatan negosiasi, serta kurang kreatif dalam mengolah kata untuk meyakinkan kepada mitra bicara, hal tersebut juga diakibatkan karena tidak ada motivasi belajar.

Dari permasalahn di atas, diperlukan media maupun strategi pembelajaran yang tepat untuk meningkatakn kemampuan negosiasi siswa. Dalam menetukan media dan strategi pembelajaran yang tepat diperlukan pemahaman mendalam pada materi pembelajaran. Media maupun strategi yang digunakan harus tepat, yaitu pemilihan media dan strategi dipilih sesuai dengan tujuan pembelajaran. Strategi pembelajaran juga dipilih berdasarkan situasi dan kondisi peserta didik. Oleh karena itu, seorang guru dituntut untuk dapat memilih dan menerapkan strategi pembelajaran serta tersampaikan dengan optimal.

Salah satu faktor yang menyebabkan hasil belajar siswa kelas XI SMK Muhammadiyah 1 Pasuruan dalam pembelajaran negosiasi adalah belum pernah menggunakan media maupun strategi pembelajaran, sehingga pembelajaran negosiasi belum berhasil secara optimal. Oleh karena itu, peneliti mencoba strategi multiple intelligences dalam pembelajaran negosiasi. Strategi ini adalah pola pembelajaran yang mengoptimalakan kemampuan/ potensi yang dimiliki oleh siswa. Dimana pada strategi ini guru memperlakukan siswanya sebagai manusia yang mempuyai kecerdasaan yang berbedabeda, dan meyelesaikan suatu masalah dengan kecerdasan yang mereka miliki, yaitu tujuan pembelajaran.

Negosiasi itu sendiri adalah Keterampilan yang memang membutuhkan latihan serta keterampilan dalam mengolah kata untuk menyakinkan seseorang. Dengan persiapan dan latihan siswa mampu menguasai lawan tutur dan dapat mempengaruhi. Yang menjadi dasar untuk negosiasi yang kreatif adalah tergantung pada penciptaan suatu iklim kerja sama dan seterusnya memulai negosiasi sedemikian rupa yang mengarahkan kedua belah pihak untuk bekerjasama secara harmonis dan kreatif. Setelah itu barulah negosiasinya sendiri mulai. Hal ini bisa diperoleh dengan mempelajari berlatih benegosiasi yang baik dengan memahami berbagai unsur yang terdapat pada kegiatan negosiasi. Oleh karena itu, peserta didik perlu mendapatkan pengetahuan mengenai pembelajaran negosiasi di sekolah.

Selain menngembangkan strategi, peneliti mengembangkan media pembelajaran berupa buku siswa, serta media barang produk yang dipilih oleh siswa. Buku siswa bermanfaat untuk memudahkan peserta dalam memahami prosedur pembelajaran dan kegiatan pembelajaran. Sedangkan media barang produk memudahkan peserta didik untuk menghasilkan produk yang nantinya memudahkan siswa dalam kegiatan negosiasi.

Berdasarkan uraian di atas, peneliti berasumsi bahwa dengan mengem-bangkan strategi dan media pembelajaran dapat meningkatkan kemampuan negosiasi peserta didik kelas XI SMK Muhammadiyah 1 
Pasuruan, dengan memanfaatkan potensi-potensi yang dimiliki oleh masing-masing peserta didik tersebut.

\section{HASIL DAN PEMBAHASAN}

Berdasarkan hasil observasi pengembangan strategi multiple intelligences pada pembelajaran negosiasi memang perlu dikembangkan, walaupun selama ini guru sudah menggunakan strategi pembelajaran yang lain untuk memudahkan peserta didik dalam meyerap pelajaran. Akan tetapi dibutuhkan pengembangan strategi pembelajaran yang lain agar peserta didik lebih aktif dalam kegiatan bernegosiasi.

Kemampuan bernegosiasi mutlak dibutuhkan Peserta didik tingkat SMK, merujuk pada out put dari SMK adalah Peserta didik yang mampu dan siap untuk terjun di dunia kerja. Seperti halnya yang dikemukakan oleh (Browdo, 2008: 11) bahwa, orang mempunyai seni bernegosiasi biasa mempunyai kehidupan yang lebih mudah.

Analisis kebutuhan sangat penting dilakukan oleh peneliti dalam pengem-bangan. Dengan mengetahui kebutuhan peserta didik, maka strategi pembelajaran yang dikembangakan akan dapat digunakan atau dimanfaatkan oleh guru dengan baik, karena memang benar-benar dibutuhkan.

$$
\text { Pembelajaran negosiasi }
$$
sangatlah diperlukan oleh peserta didik tingkat SMK, merujuk pada lulus dari SMK mereka kebayakan akan terjun di dunia kerja. Maka mereka sangat membutuhkan kemampuan dan keterampilan berbahasa yang baik, agar mereka kelak siap ketika dihadapkan pada mitra keja mereka.

Dalam

Pelaksanaanya, pembelajaran negosiasi yang diajarkan sebagian besar diajarkan dengan metode dan strategi ceramah. Padahal penggunaan strategi yang tepat dengan menggunakan media-media yang menyenangkan akan lebih memberi stimulus dan motivasi untuk siswa agar lebih berperan aktif dalam pembelajaran negosiasi, karena pembelajaran ini bertujuan untuk mengembangkan kemamapuan berbahasa, khususnya negosiasi dalam dunia kerja.

$$
\text { Pembelajaran tradisioanal }
$$

seperti ceramah pada konsep-konsep negosiasi membuat pembelajaran akan cenderung membosankan, apalagi dengan tipe Peserta didik yang berpotensi dalam bahasa, kinestetik akan cenderung pasif di dalam pembelajaran tersebut. Dengan mengembangakan strategi multiple intelligences yang mampu menggali setiap potensi dari masing-masing Peserta didik, dan menggunakan media-media yang menyenangkan, diharapkan dapat memaksimalkan pembelajaran dan memudahkan guru dalam mencapai tujuan pembelajaran. Sejalan dengan hal tersebut di atas, maka penggunakan strategi multiple intelligences dalam pembelajaran negosiasi menjadi suatu kebutuhan yang sangat penting.

Selain penggembangan strategi yang tepat pembelajaran akan lebih mudah apabila disertai dengan rangkuman materi (handout), untuk mempermudah dalam mempelajari negosiasi, sebagian sangat setuju karena pembelajaran akan lebih memudahkan dalam belajar. Bahan yang digunakan 
oleh guru dalam pembelajaran negosiasi menggunakan buku paket bahasa Indonesia yang dijual bebas. Dari bahan yang ada tersebut belum ada bahan yang meliputi komponen yang secara runtut menggajarkan kemampuan negosiasi secara berkesinambungan seperti halnya handout. Handout adalah rangkuman materi yang telah disiapkan oleh guru dengan memperhatikan keruntutan materi dan bahasa yang sudah disesuaikan dengan karakteristik Peserta didik, berbentuk cetak dan dapat dipelajari sendiri oleh Peserta didik. Handout merupakan salah satu media pembelajaran yang cukup efektif saat ini. Dengan adanya handout Peserta didik tidak perlu bersusah payah mencatat materi yang disampaikan oleh guru, sehingga Peserta didik lebih fokus pada penjelasan atau instruksi yang diberikan oleh guru.

Analisis kebutuhan guru dilakukan untuk mengetahui kebutuhankebutuhan terutama kebutuhan guru akan materi negosiasi, yang hasilnya akan digunakan sebgai dasar pengembangan strategi multiple intelligences dalam pembelajaran negosiasi di kelas XI SMK Muhammadiyah 1 Pasuruan. Bentuk strategi yang digunakan oleh guru adalah strategi pembelajaran kontekstual dengan model pembelajaran numberhand together. Dimana dalam model pembelajaran ini Peserta didik diajak untuk berkelompok untuk mendiskusikan materi negosiasi, akan tetapi model tersebut cenderung membutuhkan waktu yang lama dalam proses penilaian, maupun mengorganisir peserta didik. Bentuk materi yang digunakan dalam pembelajaran negosiasi adalah berupa buku paket pembelajaran bahasa Indonesia, yang sebagian belum sesuai dengan kebutuhan peserta didik dalam memperoleh keterampilan negosiasi.

Dengan mengetahui karakteristik Peserta didik/ Siswa penggunaan strategi yang telah dikembangkan akan disesuaikan dengan karakteristik Peserta didik sehingga strategi tersebut mudah diterapkan oleh guru. Secara umum Peserta didik cenderung kesulitan dalam melakukan praktik negosiasi, hal tersebut ditunjukkan oleh peserta didik yang sudah menerima pembelajaran tersebut. Secara umum mereka kurang bisa mengolah kata dan bahasa yang dapat menarik mitra bicara ketika melakukan praktik negosiasi. Mereka cenderung terpaku pada teks percakapan yang dibuat oleh Peserta didik sebelumnya. Yang sebenarkan tujuan dari pembuatan teks negosiasi tersebut harusnya memudahkan mereka dalam praktik negosiasi. Selain itu faktor yang membuat Peserta didik kesulitan melakukan praktik negosiasi adalah meraka belum mendapatkan sebuah gambaran secara langsung kegiatan negosiasi, karena guru hanya menggunakan metode ceramah dalam pembelajaran tersebut. Setelah melakukan analisis kebutuhan dan analisis karakter adalah mengidentifikasi tujuan umum.

Tujuan umum didapat dari identifikasi kebutuhan yang telah dijabarkan di atas. Dalam penelitian ini suatu usaha untuk mencari dan menggambarkan keperluan yang ingin dimiliki atau yang diinginkan terutama oleh Peserta didik dalam hal ini 
kebutuhan akan pembelajaran negosiasi dengan strategi pembelajaran yang mempermudah mereka dalam mencapai tujuan pembelajaran. Rumusan tujuan umum diperoleh dari daftar tujuan kurikulum dalam hal ini adalah kemampuan bernegosiasi, analisis kebutuhan belajar dan karaekteristik Peserta didik. Hasil identifikasi tujuan umum terserbut adalah sebagai berikut; 1) peserta didik mampu mengemukakan ide, gagasan, atau komentar yang menarik dan santun sesuai dengan memperhatikan topik bahasan, 2) peserta didik mampu menyanggah pendapat orang lain dengan santun dan tetap menghargai pendapat mitra bicara, 3) peserta didik mampu meyakinkan mitra bicara/ kerja untuk menyepakati ide yang dikemukakan dengan sikap dan kalimat yang cermat, serta argumentasi yang rasional.

langkah terpenting sebelum mengembangkan strategi pembelajaran adalah merancang terlebihdahulu pembelajaranya. Dari tujuan di atas dilakukan identifikasi standar kompentensi dan kompetansi dasar, selanjutnya ditentukan materi pokok yang akan dibelajarkan. Standar kompetensi dianalis untuk mengenali keterampilan-keteampilan bawahan yang mengharuskan Peserta didik belajar menguasainya dan langkahlangkah procedural yang ada harus diikuti Peserta didik untuk dapat belajar. Analisis ini menghasilkan suatu simpulan dalam bentuk peta atau diagram yang mengambarkan keterampilan-keterampilan yang ditemukan itu dan menunujukkan hubungan-hubungannya.
Hasil

perhitunggan menunjukkan bahwa hasil belajar peserta didik mengalami peningkatan peningkatan dilihat dari rata-rata nilai pretes sebesar $66 \%$ menjadi $84,13 \%$. N menunjukkan banyaknya data sebesar 31 peserta didik. Pada output kedua nilai korelasi antara pretes dan postes adalah 0,101 artinya keduanya mempunyai hubungan signifikan, Sedangkan ratarata dua nilai tersebut sebesar 18,129. Pada df (derajat kebebasan), untuk uji $\mathrm{T}$ paired selalu N-I, dimana df adalah 31$1=30$. . Nilai $t_{\text {hitung }}$ harus dibandingkan dengan nilai $t_{\text {tabel, }}$ apabila nilai $t_{\text {hitung }}>t_{\text {tabel }}$ maka data tersebut signifikan. Hasil analisis didapat $t_{\text {hitung }}$ sebesar 10.713, sedangkan $t_{\text {tabel }}$ dengan taraf signifikan 5\% sebesar 1,697. Dari dua angka tersebut dapat diketahui bahwa $\mathrm{t}_{\text {hitung }}$ lebih besar dari $t_{\text {tabel }}(10.713>1,697)$.

Berdasarkan hasil analisis statistik di atas perolehaan hasil postes pada kelas dibandingkan dengan perolehan hasil pretes. Jadi dapat dipaparkan bahwa terdapat perbedaan antara pembelajaran negosiasi dengan menggunakan strategi multiple intelligences dan tanpa menggunakan strategi multiple intelligences. Hasil statistik menunjukkan hasil belajar pada prostes sebesar $84,13 \%$ lebih besar dari hasil pretes $66 \%$ lebih.

Hasil temuan dalam penelitian ini adalah peserta didik lebih semangat dan termotivasi dalam mengikuti pembelajaran dengan strategi multiple intelligences dari pada pembelajaran yang dilakukan oleh guru sebelum perlakukan. Hal ini terbukti dari nilai hasil antara pretes dan postes.

Dengan demikian dapat disimpulkan bahwa strategi multiple 
intelligencesefektif dalam pembelajaran negosiasi peserta didik kelas XI SMK Muhammadiyah 1 Pasuruan.

\section{SIMPULAN DAN SARAN}

Analisis kebutuhan peserta didik pembelajaran negosiasi sangatlah diperlukan oleh peserta didik tingkat SMK, merujuk pada lulus dari SMK mereka kebayakan akan terjun di dunia kerja, maka mereka sangat membutuhkan kemampuan dan keterampilan berbahasa yang baik, agar mereka kelak siap ketika dihadapkan pada mitra keja mereka. Pembelajaran tradisioanal seperti ceramah pada konsep-konsep negosiasi membuat pembelajaran akan cenderung membosankan, apalagi dengan tipe Peserta didik yang berpotensi dalam bahasa, kinestetik akan cenderung pasif di dalam pembelajaran tersebut. Dengan mengembangakan strategi multiple intelligences yang mampu menggali setiap potensi dari masing-masing Peserta didik, dan menggunakan mediamedia yang menyenangkan, diharapkan dapat memak-simalkan pembelajaran dan memudahkan guru dalam mencapai tujuan pembelajaran. Sejalan dengan hal tersebut di atas, maka penggunakan strategi multiple intelligences dalam pembelajaran negosiasi menjadi suatu kebutuhan yang sangat penting.

Selain penggembangan strategi yang tepat pembelajaran akan lebih mudah apabila disertai dengan rangkuman materi (handout), untuk mempermudah dalam mempelajari negosiasi, sebagian sangat setuju karena pembelajaran akan lebih memudahkan dalam belajar. Analisis kebutuhan guru bentuk strategi yang digunakan oleh guru adalah strategi pembelajaran kontekstual dengan model pembelajaran numberhand together. Dimana dalam model pembelajaran ini Peserta didik diajak untuk berkelompok untuk mendiskusikan materi negosiasi, akan tetapi model tersebut cenderung membutuhkan waktu yang lama dalam proses penilaian, maupun mengorganisir Peserta didik.

Bentuk materi yang digunakan dalam pembelajaran negosiasi adalah berupa buku paket pembelajaran bahasa Indonesia, yang sebagian belum sesuai dengan kebutuhan Peserta didik dalam memperoleh keterampilan negosiasi. Analisis karakteristik peserta didik secara umum Peserta didik cenderung kesulitan dalam melakukan praktik negosiasi, hal tersebut ditunjukkan oleh Peserta didik yang sudah menerima pembelajaran tersebut. Secara umum mereka kurang bisa mengolah kata dan bahasa yang dapat menarik mitra bicara ketika melakukan praktik negosiasi. Mereka cenderung terpaku pada teks percakapan yang dibuat oleh Peserta didik sebelumnya. Yang sebenarkan tujuan dari pembuatan teks negosiasi tersebut harusnya memudahkan mereka dalam praktik negosiasi. Selain itu faktor yang membuat Peserta didik kesulitan melakukan praktik negosiasi adalah meraka belum mendapatkan sebuah gambaran secara langsung kegiatan negosiasi, karena guru hanya menggunakan metode ceramah dalam pembelajaran tersebut. Identifikasi tujuan khusus tujuan umum dan hasil analisis pembelajaran, adapun hasil dari identifikasi tujuan khusus adalah sebagai berikut. 
1. Peserta didik diharapkan memiliki pemahaman yang memadai tentang konsep negosiasi

2. Peserta didik diharapkan memiliki pemahaman tentang struktur dan kaidah teks negosiasi dengan menggunakan bahasa Indonesia dan menggunakannya sebagai sarana komunikasi dalam bernegosiasi

3. Peserta didik diharapkan memiliki pemahaman tentang melakukan pola gilir dalam bernegosiasi.

4. Peserta didik diharapkan memiliki kemampuan menyusun teks negosiasi dengan tepat

5. Peserta didik diharapkan memiliki kemampuan untuk praktik negosiasi dan mampu membuat inisiasi terhadap mitra bicara.

Langkah berikutnya adalah menyusun rancangan pelaksanaan pembelajaran negosiasi dengan strategi multiple intelligences. Langkah ini menghaslkan rancangan pembelajaran berupa RPP dan handout pembelajaran. Sedangkan hasil uji coba pada pretes menunjukkan bahwa peserta didik banyak yang tuntas dalam belajar. Secara klasikal rata-rata 83,55 telah memenuhi standar ketuntasan belajar.

Berdasarkan hasil pengamatan pada kegiatan posttest dimana peserta didik melakukan pembelajaran negosiasi dengan strategi multiple intelligences, Peserta didik mengalami kemajuan dalam hasil belajar hal tersebut terjadi karena adanya motivasi lebih yang dilakukan oleh guru sehingga peserta didik bergairah dalam mengikuti setiap langkah-langkah kegiatan yang sudah atur oleh guru.Sebanyak 96,8 \% dihitung dari jumlah peserta didik yang mendapat nilai $>75$ sebanyak 30 peserta didik, sedang yang belum tuntas belajar sebanyak 3,2 \% dihitung dari jumlah peserta didik yang mendapatkan nilai $\checkmark 75$ sebayak 1 Peserta didik. Faktor lain yang membuat kemajuan dalam hasil belajar peserta didik adalah kegiatan warmer dalam bentuk game. Pembelajaran yang diselinggi oleh game membuat peserta didik merasa tidak terbebani, lain dengan guru yang menunjuk peserta didik untuk menjawab pertanyaan yang diajukan oleh guru secara spontanitas. Apabila hal tersebut dilakukan pada awal pembelajaran, maka peserta didik menjadi stress dan membuat motivasi peserta didik menurun, bahkan enggan mengikuti pelajaran guru tersebut. Barang produk ternyata juga efektif dalam pembelajaran karena mempermudah peserta didik ketika mereka mengalami lupa teks dengan memanfaatkan barang produk yang tersedia.

Hasil analisis didapat $t_{\text {hitung }}$ sebesar 10,713 , sedangkan $t_{\text {tabel }}$ dengan taraf signifikan 5\% sebesar 1,697. Dari dua angka tersebut dapat diketahui bahwa $t_{\text {hitung }}$ lebih besar dari $t_{\text {tabel }}$ $(10,713>1,697)$ Jadi dapat dipaparkan bahwa terdapat perbedaan antara pembelajaran negosiasi dengan mengguna-kan strategi multiple intelligences dan tanpa menggunakan strategi multiple intelligence.

Hasil temuan dalam penelitian ini adalah peserta didik lebih semangat dan termotivasi dalam mengikuti pembelajaran dengan strategi multiple intelligences dari pada pembelajaran yang dilakukan oleh guru sebelum perlakukan. Hal ini terbukti dari nilai hasil antara pretes dan postes. 
Dengan demikian dapat disimpulkan bahwa strategi multiple intelligencesefektif dalam pembelajaran negosiasi peserta didik kelas XI SMK Muhammadiyah 1 Pasuruan.

Pengembangan strategi multiple intelligences ini merupakan salah satu upaya untuk mengatasi kesulitan peserta didik dan guru dalam pembelajaran negosiasi. Selanjutnya apabila pengembangan strategi dalam penelitian ini sudah tersusun, sekolah tingkat menengah kejuruan (SMK) dapat memanfaatkannya sesuai dengan kepentingan masing-masing.

Strategi pembelajaran yang dikembang-akan nantinya berupa perangkat pembelajaran dan handout. Penggunaan strategi multiple intelligences ditunjang dengan adanya handout akan memudahkan siswa dalam pembelajaran negosiasi.Sedangkan guru mampu merancang, melaksanakan, dan mengevaluasi pembel-ajaran negosiasi dengan menggunakan strategi multiple intelligences.

\section{DAFTAR RUJUKAN}

Alim. 2011. Pengembangan Model

Rencana Pelaksanaan

Pembelajaran BahasaIndonesia

Berbasis Kecerdasan Majemuk di

SmP Negeri 4 Jombang. Tesis

tidakditerbitkan. Malang Program

Pascasarjana Universitas Islam

Malang

Brodow, Ad. 2008. Negosiasion boot camp: latihan singkat bernegosiasi jitudisegala situasi. Jakarta: PT Serambi Ilmu Semesta Anggota IKAPI

Chatif, Munif A. 2011. Gurunya

Manusia: Menjadikan Semua Anak
Istimewa dan Semua Anak Juara. Bandung: PT. Mizan pustaka Chatif, Munif B. 2011. Kelasnya Manusia: Memaksimalkan Fungsi Otak belajar dengan Manajemen Display Kelas. Bandung: PT. Mizan pustaka

Majid, Abdul. 2005, Perencanaan Pembelajaran (mengembangkan kompe-tensi guru).(Online), (http://id.pengertianpengembangan/, diakses 25 maret 2014).

Mulyatingsih, Endang. 2011. Metode Peneliyian Terapan Bidang Pendidikan.Bandung: Alfabeta

Mistar, Junaidi. 2007. Handout Statistics for Language Teaching Studies. Malang:Program Studi Pendidikan Progran Pascasarjana Universitas Islam Malang

Mistar, Junaidi. 2010. Pedoman Penulisan Tesis. Malang: Program PascasarjanaUniversitas Islam Malang

Sanjaya, Wina. 2006. Strategi Pembelajaran: Berorientasi Standar Proses

Pendidikan. Jakarta: Kencana Prenada Media.

Setyosari, Punaji. 2013. Metode Penelitian Pendidikan dan Pengembangan. Jakarta:Kencana

Tarigan, Henry Guntur. 2008. Berbicara (sebagai Suatu

KeterampilanBerbahasa). Bandung: Angkasa

Wahyuni, Sri dan Abd. Syukur Ibrahim. 2012. Asesmen Pembelajaran

Bahasa. Bandung: Refika Aditama 